Article

\title{
Entrepreneurial Intention among Rural Youth in Moroccan Agricultural Cooperatives: The Future of Rural Entrepreneurship
}

\author{
El Houssain Bouichou ${ }^{1,2, *}$, Tahirou Abdoulaye ${ }^{3}$, Khalil Allali ${ }^{1}$, Abdelghani Bouayad $^{4}$ and Aziz Fadlaoui ${ }^{2}$ \\ 1 Department of Economic and Social Sciences Applied to Agriculture, Agronomic and Veterinary Institute \\ Hassan II, Madinat Al Irfane, B.P. 6202, Rabat 10101, Morocco; kallali@enameknes.ac.ma \\ 2 Economics and Sociology and Quality Regional Agricultural Research Center Km 10, Research Unit \\ Management of Natural Resources, Haj Kaddour Road, P.O. Box 578 (VN), Meknes 50000, Morocco; \\ aziz.fadlaoui@inra.ma \\ 3 Social Science and Agribusiness, International Institute of Tropical Agriculture (IITA), B.P. 320, \\ Bamako 91094, Mali; T.Abdoulaye@cgiar.org \\ 4 Laboratory for Social Sciences and Economics, Faculty of Economic and Social Legal Sciences, Moulay Ismail \\ University, B.P. 3201 Toulal, Meknes 50000, Morocco; bouayad_abdelghani@hotmail.com \\ * Correspondence: lhoussain.bouichou@inra.ma
}

Citation: Bouichou, E.H.; Abdoulaye, T.; Allali, K.; Bouayad, A.; Fadlaoui,

A. Entrepreneurial Intention among Rural Youth in Moroccan Agricultural Cooperatives: The Future of Rural Entrepreneurship. Sustainability 2021, 13, 9247. https://doi.org/10.3390/ su13169247

Academic Editor: Marco Vivarelli

Received: 5 July 2021

Accepted: 8 August 2021

Published: 18 August 2021

Publisher's Note: MDPI stays neutral with regard to jurisdictional claims in published maps and institutional affiliations.

Copyright: (c) 2021 by the authors. Licensee MDPI, Basel, Switzerland. This article is an open access article distributed under the terms and conditions of the Creative Commons Attribution (CC BY) license (https:// creativecommons.org/licenses/by/ $4.0 /)$.

\begin{abstract}
Rural entrepreneurship in the developing world has long been hailed as a powerful tool for promoting the socioeconomic integration of young people and the key to avoiding rural depopulation as well as ensuring these areas remain attractive places for rural youth. However, there have been no efforts to investigate the role of collective entrepreneurship in the creation and management of new businesses in Morocco. Furthermore, we build on the theory of planned behavior (TPB) to investigate and explain entrepreneurial intention among the rural youth members of agricultural cooperatives, and identify the vulnerabilities and factors that influence the choice or decision-making between permanent membership at the cooperative and an entrepreneurial career. In this case, we apply the cognitive approach to survey rural youth in the Drâa-Tafilalet region of Morocco in 2020. The binary logistic regression analysis technique has been used and applied to build the best model to explain why some rural youth members of the cooperative, but not others, choose to become entrepreneurs. We model how agricultural cooperatives may favor or inhibit the translation of entrepreneurial intention into new venture creation. A random sample size of 130 young people has been selected, from which 54 are intending to start a business and 76 have a negative intention of self-employment. The results of the analysis showed that socio-demographic variables, individual perceptions, previous experience, and the activities of the cooperative were statistically significant and reliable in building the binary logistic regression model. Findings also suggest that the risks of agribusiness and financing constraints have a negative influence on entrepreneurial intentions of the youth and women in agricultural cooperatives.
\end{abstract}

Keywords: agribusiness; agricultural cooperative; entrepreneurial intention; logistic regression; rural development; youth entrepreneurship

\section{Introduction}

Recent literature on African rural youth has emphasized the importance of entrepreneurial culture for rural youth [1-5]. In this context, entrepreneurship in rural areas is conceived as a key part of rural development to create employment opportunities for young people, as it tackles their migration at its root causes [6]. Presently, empirical studies pay special attention to entrepreneurship among African youth in rural areas through the opportunities offered by the agricultural sector or the large numbers of young people that continue to live in rural areas, focusing on the youth unemployment problem [3]. Although entrepreneurial activity is not the only way to reduce youth unemployment and create income-generating activities, it is 
certainly one of the essential elements and a fundamental requirement. Today, policymakers in many African countries, including Morocco, have widely acknowledged the role of rural entrepreneurship as the engine of rural development [7]. Recent research on entrepreneurship has focused largely on motivation that includes items, each covering potentially different motivations. Several motives exist for undertaking an entrepreneurial venture [8]. Some studies distinguish between innovative and non-innovative entrepreneurial activities by placing the innovative entrepreneur at the heart of the dynamics of capitalism [9].

The development of the cooperative movement has emerged as an important, interesting, and challenging consideration in public institutions. These various institutions intervene in socioeconomic programs. Each of them carries out actions to achieve specific objectives, but the results have been less than impressive [10]. In fact, many public institutions that assist small farmer organizations prove to be, in the absence of rigorous scrutiny and evaluation of entrepreneurial difficulties, a source of constraints that limit the impact of public actions believed to be in favor of these organizations. The weak results posted by a number of agricultural aggregation projects still constitute huge constraints for cooperatives' development. Although the impact of the Green Plan of Morocco on rural development and the cooperative sector has been evaluated, despite the extensive literature suggesting adaptations to avoid negative impacts, there has been less examination of failure resulting from entrepreneurial capacity. This paper focuses on how entrepreneurial intention of women and men affects the success or failure of policies and programs.

Other studies distinguish between opportunity and necessity in entrepreneurship activities. Capital investment tends to play a more important role in the opportunity for entrepreneurship, while drawing on economic opportunities or simply seeking autonomy. In the context of limited financial capital resources, simple unemployment, or general dissatisfaction with the current situation, more of the youth are willing to exhibit increased motivation [11]. In rural areas, young people have low intentions of becoming entrepreneurs in agriculture due to project financing factors, which involve substantial capital investments and are subject to a high level of risk [12]. Further research has shown that the attitude factor also influences the intentions of youth entrepreneurship in the agricultural sector. Other factors such as entrepreneurial perceptions, which differ according to their degree of importance as well as their scale of impact, can explain why some of the rural youth, but not others, choose to become entrepreneurs. The perceptions and intentions can be linked to individual perceptions, such as self-efficacy, socio-culture, especially the social legitimation of entrepreneurship, and perceptions about opportunities, where entrepreneurs discover and exploit opportunities which promote the development process [13-16].

Social learning factors can be identified as individual perceptions affecting entrepreneurial intentions among the youth that reflect their entrepreneurial attractiveness [17]. Many empirical studies have been conducted on the perceptions of young people living in the countryside and in urban areas, both young graduates and young illiterate workers, to explain the reasons why youth create businesses [17]. However, there is no extensive empirical research on factors that influence entrepreneurial intentions of young members of agricultural cooperatives.

Furthermore, agricultural cooperatives are becoming increasingly important for the social, environmental, and economic fabric of rural areas. According to [18], the vertical coordination of cooperatives is the appropriate vehicle to reduce transaction costs and link smallholder farmers to markets. Thus, cooperatives are considered to be information workspaces for members, i.e., they provide various services involved in the production and sales process, to generate greater profits by obtaining input factors and services from the upstream and downstream supply chain [19]. In other words, cooperatives stimulate transactions to minimize the various stages of the value chain, help agricultural producers become participants, and increase their share of the benefits [20].

In fact, since the creation of the Moroccan Office for the Development of Cooperation (ODCO) in 1963, agricultural cooperatives have played an important role in rural development, as they guaranteed the rural population their legitimate right to collaborative work 
with a view to improving the economic and social situation. Cooperative societies are an appropriate solution for rural youth and women who both have no resources and lack financial capital as well as access to land.

In recent years, policymakers are increasingly encouraging the development of rural entrepreneurship to revitalize rural communities across Morocco [21]. In addition, these cooperatives and youth entrepreneurship, in particular, are the key engines to sustainable growth in the future because of the potential of the youth to make a great contribution to agribusiness and rural economic activities [22]. At the same time, youth unemployment is a major problem in Morocco, whether in urban or rural areas. The present challenge lies simultaneously in creating jobs for the bulging youth population and satisfying the expectations of young people and society alike. Youth employment and matching skills are essential components for economic and social stability.

Despite government policies, economic growth has not translated into the creation of decent jobs. The employment rate decreased from $47 \%$ to $46.7 \%$ [23] between 2016 and 2017. Furthermore, even if the Government of Morocco and various development partners focus on the rural youth employment challenge regarding the support of small enterprise development, systemic challenges persist for these young people, such as a lack of access to finance, business training, and mentoring. There is a lack of specialized programs to support young entrepreneurs in rural and remote contexts. In recognition of youth's low interest, the Moroccan Government launched a massive new Integrated Program for Enterprise Support and Financing [24], with the aim of developing the agricultural sector through incorporating entrepreneurship activities, answering rural youth unemployment, and encouraging the emergence of a rural middle class. Accordingly, the interest rate will be $1.75 \%$, despite the higher credit risk arising from the narrow market, weather vagaries, and large variations in the prices of agricultural products [25]. An initial assessment of the program is necessary to discover how successful the program has been in its ability to increase business intentions in the first year.

The guarantee of long-term sustainability of rural enterprises requires the youth to develop specific capabilities and competencies, among which entrepreneurial competencies [7] are the most important. Moreover, the development of innovative rural youth in management, marketing, and business is likely grown along with the work life inclusion that is expected to continue. The development of rural entrepreneurship can be profoundly influenced by close attention to the diversity of the experience acquired by young people in agricultural cooperatives. If rural youth are empowered by entrepreneurial competencies, their intention to establish businesses in rural areas will be strengthened. However, empirical investigations recently conducted have not adequately addressed, within an integrated framework, the questions as to what extent the experiences of rural youth in agriculture would impact the future of rural entrepreneurship and how they would promote the intention to establish rural business activities. This subject therefore calls for an empirical study to provide key basic data on the factors that influence the intentions of young members of agricultural cooperatives, identify the roles of the experience acquired in collective entrepreneurship, and address information gaps around the intentions of the young members. As well as their capability, their perspectives were sought about self-employment in the future of rural agribusiness. The main objective of this study is to investigate and explain entrepreneurial intention among the rural youth members of agricultural cooperatives as well as identify the vulnerabilities and factors that influence the choice or decision-making between a permanent membership at the cooperative and an entrepreneurial career. In order to serve the main objective, the study sets the following three specific objectives: (i) to identify the determinants of entrepreneurial intention among Moroccan youth in rural areas; (ii) to identify the significance of previous experience and the activities of the cooperative for rural youth in encouraging them to start up a business; and (iii) to distinguish between the activities of the agricultural cooperatives and different perceptions related to entrepreneurial intentions in the determination of the future of rural entrepreneurship. The focus of this paper revolves around problems of 
entrepreneurial behavior and their impact on the future of agribusiness in rural areas. This paper is organized as thus: following this introduction, Section 2 sets out the literature review. Section 3 presents the empirical strategy. Results are presented in Section 4 and are then discussed and concluded in Section 5. The paper finishes with brief implications for policy development.

\section{Literature Review}

The theory of planned behavior (TBP) can be used as the basis for the analysis of entrepreneurial intentions [12]; in the rural entrepreneurship context the relevant literature has studied the influence exerted by some attitudes on the perceptions to start up agribusinesses [13]. An attitude has been defined [26] as the extent to which one perceives entrepreneurial behavior and its significance as beneficial, valuable, and promising. According to [27], the intentions of youth to engage in entrepreneurship in rural areas are influenced by the attitudinal factors that are identical to individual competency, which refers to the willingness to conduct a certain behavior. A model was developed [28], which took into account the theory of planned behavior (TPB) for checking how entrepreneurial intention is determined by the personal attitude toward entrepreneurship, by how subjective norms are perceived, and also by behavioral control, which is influenced by demographic factors. Quite a large body of empirical literature is based on the TPB that documents the dimensions for entrepreneurial intentions among the youth, including personal control over behavior and the need for achievement, self-esteem, and innovation [13,28], and identifies potential entrepreneurship behavior and its influence on the outcomes of venture creation. The cognitive approach uses cognitive aspects to explain entrepreneurial behavior through cognitions. The field of entrepreneurial cognition includes all aspects of cognition that can potentially play an important role in certain aspects of the entrepreneurial process. Two main lines can be differentiated within the cognitive literature: the study of cognitive structures and the study of cognitive processes. Cognitive structures represent and contain knowledge, while cognitive processes relate to the manner in which that knowledge is received and used. Thus, self-efficacy is the main cognitive aspect reflected in the literature that sheds light on the study of entrepreneurship [28]. Accordingly, it is crucial to focus on possible factors that might influence the development of self-efficacy. Therefore, we seek to ascertain the impact of the social environment on the self-efficacy beliefs of rural youth members of agricultural cooperatives, with questions on support from family and friends, opportunities, and obstacles to entrepreneurial initiatives in rural areas [13].

However, in relation to the intention to start up a business, it is the cognitive approach that has awakened the highest interest among the youth [28]. According to [29], "entrepreneurial cognitions are the knowledge structures that people use to make assessment, judgment, or decisions involving opportunity evaluation, venture creation and growth". This cognitive approach in the research field of entrepreneurship emphasizes the importance of perceptions of it rather than the personal qualities of the youth [28]. These factors are the predictors of how far the young adult is ready to start a business, manage it, and assume the risks of an agribusiness or agri-enterprise. The stronger the social status, attitude towards entrepreneurship, internal market dynamics, and physical infrastructure, the greater the probability of actually starting a business. Figure 1 presents the TBP developed by [29], or the analysis of entrepreneurial intentions. In his model, the intention is assumed as the portrait of a motivation factor that affects action. This indicates that how hard a person tries to formulate behavior for intention is highly correlated with behavior. There are three distinct factors of intention: (i) attitude toward the behavior (refers to how far an individual assesses something as favorable or unfavorable), (ii) subjective norm (experience of a social pressure to do or behave in a certain way), and (iii) perceived behavioral control (a perceived easiness or trouble that is formed from assumptions based on past experience and anticipation of obstacles and barriers). 


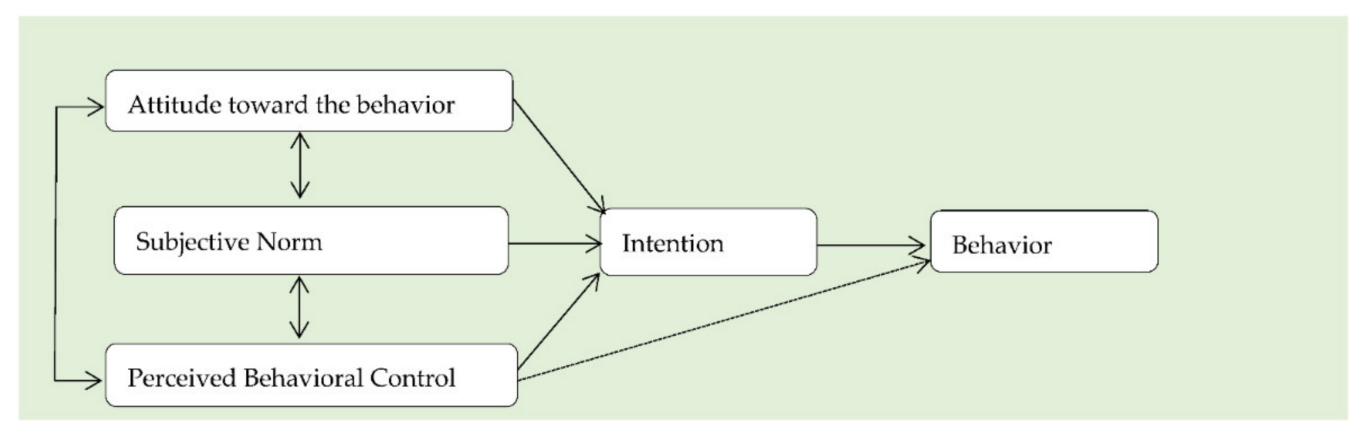

Figure 1. Theory of planned behavior. Source: Ajzen (1991).

Several studies in developing countries provide evidence for the applicability of the TPB in the context of youth entrepreneurship. For instance, the authors of [30] studied entrepreneurial intentions and perceived barriers to entrepreneurship among the youth and found entrepreneurial intentions that focus on the effect of gender from a crosscultural perspective, including opportunity recognition, creativity, problem solving skills, leadership and communication skills, development of new products and services, and networking skills. Their results confirm that there is an effect of gender and regional culture on the perceived barriers to entrepreneurship and entrepreneurial intentions, particularly on the youth. The authors of [31] investigated the attitude of African youth towards the creation of new business and entrepreneurship where study results suggest the existence of an active positive attitude among young entrepreneurs that are ready to take risks and stand alone. The authors of [32] have used [29] the TPB to investigate the impact of relevant courses on entrepreneurial intentions of students in agriculture. Their results show that the entrepreneurship education program has affected the students' perceived behavioral control and has had the anticipated positive and negative effects.

According to research that was done [12], there are several factors that influence young people to become agricultural entrepreneurs. These factors, which are extracted from the literature review, are socio-demography and youths' skills, vocational experience, attitudes, and educational qualifications. There is, however, a lack of sufficient data regarding entrepreneurial intentions and the incentives offered to young members of agricultural cooperatives. Recent empirical evidence considered that socio-demography was the first factor that affects the attitude of the youth and their acceptance of agricultural entrepreneurship. See [33,34]. It includes age, gender, income, youth status, and education level. Demographic factors are the variables that are influencing the youth to take up agricultural entrepreneurship in Indonesia [12]. Demographic variables that had been studied were gender, age, income, locality, and ethnicity [12,32].

Age is one of the most widely studied socio-demographic characteristics. According to [35], individuals between the ages of 25 and 40 years were more likely than others to start a new business venture because they had obtained sufficient experience in entrepreneurship. This experience is only one example that demonstrates that there are many competencies, such as self-confidence, a positive, professional attitude, and the ability to do business within the rural area. The gender of an individual is another widely studied determinant of entrepreneurship. In recent years, research on both topics experienced rapid expansion and ventured in new directions [36]. Furthermore, the authors of $[37,38]$ suggested that the self-employment sector was traditionally thought to be the domain of the male gender. They explained the reduced entrepreneurial spirit among women through low gender income and education gaps as well as women's household duties and marital status (see, for example, $[3,39])$.

The importance of education level and training with regard to entrepreneurship intention has been underlined in several pieces of research. According to [40], education has a major impact on the technical information a young adult has on different career choices, opportunities, and the degree of financial support available. The authors of [40] draw on social cognitive career theory to examine the relationship between entrepreneurial intention 
and creating a new venture (i.e., the entrepreneurial career choice). Using unique longitudinal data from almost the entire population of Italian university graduates, entrepreneurial intentions were measured before graduation. Their results show that context plays an important role in explaining why youth do or do not act on their intentions. Relevant others and organizational influences enhance individuals' likelihood of creating a new venture, whereas environmental influences may inhibit the creation of a new venture [41]. An important element to consider is that a lower level of education does not provide sufficient opportunity for employment for economically active young adults and therefore contributes to their decisions to start their own businesses [42].

The remaining studies tested the effect of family circumstances. One of these studies [43] hypothesized that an increase in family responsibility, widely modeled by the number of children or number of dependents, reduces the probability of an individual choosing self-employment since it increases the cost of business failure. In terms of work experience capturing entrepreneurial behavior and the degree to which entrepreneurship is positively correlated with work experience [43], an important variable for the intention of the entrepreneur is the motivation from success gained by exploiting an opportunity. In their study, the authors of [43] explain that the opportunistic entrepreneur is an individual who goes into entrepreneurship as a result of prevailing attractive business opportunities. According to their study, individuals who become opportunistic entrepreneurs consider many factors, which include the economic environment as well as institutional and governmental policies. A number of authors also argue how personal knowledge, past experience, and entrepreneurial skills can help to enhance the process of identifying investment opportunities for young adults $[44,45]$.

Several different studies report gender differences in the search for business opportunities. The authors of [43] claim that men and women differ in some aspects of searching for opportunity. The link with intention experience in the entrepreneurial context may therefore be stronger than in many other contexts. Indeed, daily confrontation with the work of another individual can bring not only well-developed technical knowledge but also a good network that is essential to new ventures and is mainly acquired through practical experience in the business [43]. In the TPB-inspired model considered here, socio-economic variables and personal attitudes can have a strong influence on entrepreneurial intention, alongside perceived behavioral control. To develop our hypotheses, we bridge different literatures and theoretical perspectives. Specifically, we combine the theory of planned behavior and related existing research on entrepreneurship in rural areas. Based on this our model hypotheses are as follows:

Hypothesis 1 (H1). Personal and socio-economic variables will exert a positive effect on entrepreneurial intentions.

Hypothesis 1a (H1a). Socio-demographic variables positively influence entrepreneurial intentions.

Hypothesis $\mathbf{1 b} \mathbf{( H 1 b ) . ~ I n d i v i d u a l ~ p e r c e p t i o n s ~ p o s i t i v e l y ~ i n f l u e n c e ~ e n t r e p r e n e u r i a l ~ i n t e n t i o n s . ~}$

Considering the role of socio-demographic and economic factors on the capacity to generate future business, such as gender, age, education level, and income level of rural youth $[12,33,34,39]$, there is a strong conceptual and empirical basis that shows the importance of the link between creativity and socio-demographic characteristics [32]. However, other factors related to public territorial actions and market dynamics play a role as well [43]. Based on the above argument, our second hypothesis is as follows:

Hypothesis 2 (H2). Activities of cooperatives and participation in the agricultural cooperative substantially enhance entrepreneurial intentions among the rural youth.

Hypothesis 2a (H2a). Work experience within agricultural cooperatives positively influences entrepreneurial intentions. 
Hypothesis $\mathbf{2} \mathbf{b} \mathbf{( H 2 b )}$. The cooperative's activity sector has an impact on young members with regard to starting a business.

The most successful collective actions are characterized by very strong dynamics and the reflection of a labor market in permanent evolution. In particular, on the one hand, young people in the agricultural cooperatives are assumed to be open to new experiences, and hence their collaborations with each other are expected to be more effective with regard to starting a business [43]. On the other hand, there is a business opportunity in rural areas, which has a positive impact on entrepreneurial intention of the youth and hence further integrates young people into employment [7]. Moreover, there is diversity of entrepreneurship (such as necessity- versus opportunity-based) and activities in the rural environment that nurture the generation with new and novel ideas, as well as knowledge, and therefore increases the number of self-employed individuals that will encourage entrepreneurial activity. In other words, those cooperatives in which young people are active in and integrate with provide a stimulating associative activity that connects them in the agricultural sector and rural economy [46].

This should be particularly true for entrepreneurial activities conducive to private sector development, entrepreneurship, and innovation. The public actions are however insufficient to promote entrepreneurship in rural areas. In fact, fear of failure negatively influences entrepreneurial intention of the youth. This entails assuring concrete measures in the field of entrepreneurship, in particular access to finance, training, and improving business climate $[40,42,44]$. Therefore, our third hypothesis is as follows:

Hypothesis 3 (H3). Factors which characterize the rural environment influence entrepreneurial intention of the youth.

Hypothesis 3a (H3a). Financing constraints negatively influence entrepreneurial intention of the youth and women members of agricultural cooperatives.

Hypothesis $3 \mathbf{b} \mathbf{( H 3 b )}$. Fear of failure negatively influences entrepreneurial intention of the youth.

Hypothesis 3c (H3c). Business opportunities in rural areas positively influence entrepreneurial intention of the youth.

\section{Empirical Strategy}

\subsection{Description of the Study Area}

This study was undertaken in the Drâa-Tafilalet region, established under Decree No 2.15.10 on 20 February 2015, establishing the number of regions in the kingdom, their names, their capitals, and the provinces from which they are composed. It was set up as part of implementing the advanced regionalization adapted by the Moroccan Constitution of 2011 [47]. This new regional division led to the emergence of Drâa-Tafilalet, the largest border region of Morocco (Figure 2). According to the last General Population and Housing Census [48], this region accounts for 1,635,008 inhabitants (compared with 1,493,347 in 2004). The rural population of the region is $1,074,270$, representing $65.8 \%$ of its total population, and $60 \%$ of the population of the region is situated in the age range of 15 to 60 years. Consequently, the provinces in the Drâa-Tafilalet region are characterized by the importance of the rural territory and the younger population.

According to [49], the region's economy is based upon three levels of wealth: agriculture, energy and mines, and finally, tourism, art, and the cultural industry. These levels have common points that link them, allowing the emergence of a circular economy for the benefit of the population in the region. The future of the region is also very promising, and therefore offers investment opportunities that need to be seized. The growth sectors are agriculture; crafts; energy and mines; agribusinesses; and tourism. 


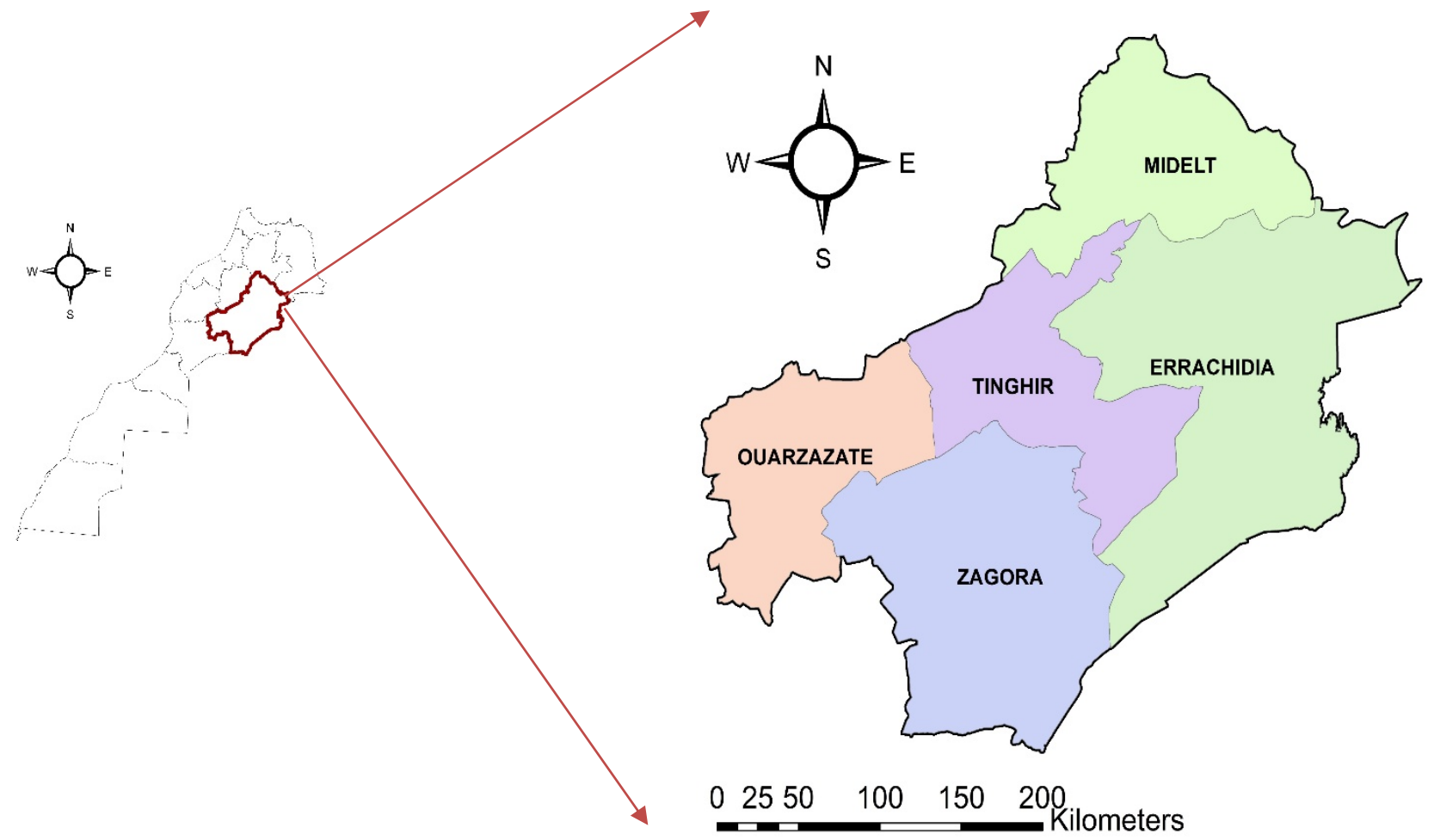

Figure 2. Map of the study area-Draa-Tafilalet region.

The Drâa-Tafilalet region covers $88,836 \mathrm{~km}^{2}$, making up $12.5 \%$ of the national territory and $46 \%$ of the Moroccan oasis zone. It is limited by the region of Fez Meknes and the region of Beni Mellal-Khénifra to the north, by the oriental region and Algeria to the east, to the west by the Marrakech-Safi and Souss-Massa regions, and by Algeria to the south [47]. Administratively, the region of Drâa-Tafilalet consists of the following:

(1) Five provinces: Errachidia, Ouarzazate, Zagora, Midelt, and Tinghir

(2) Townships totaling 125 in number: 16 urban towns and 109 rural towns

Taking into consideration the great potential of the region, the establishment of youthheaded cooperatives supported the integration of young people into the labor market and encouraged investment and entrepreneurship. There are 1814 cooperatives in the DrâaTafilalet region with 49,418 members [49]. These will be determining factors in economic development and also in the increase in job opportunities. The study areas have a high diversity in agricultural cooperative types: medicinal and aromatic plants, agribusinesses, the dairy industry, honey producers, mutton producers, and olive oil producers.

A simple random sampling technique was used to select the groups from which the respondents were drawn. The list of registered agricultural cooperatives groups as obtained from the Moroccan Office for the Development of Cooperation (ODCO) was used as the sample frame. Similarly, young respondents were identified from the sampled cooperatives groups by simple random sampling. For the purpose of this study, data from a sample of 130 young members of agricultural cooperatives were collected, which covers more than 10 cooperatives across six rural communities of the Drâa-Tafilalet region. The response group consisted of $130(46.2 \%)$ female respondents and $113(53.8 \%)$ male respondents. Fifty-four (41.54\%) responded by saying that they intended to start a business within three years, while 76 (58.46\%) were not thinking about individual business units.

\subsection{Data Collection Instrument}

Drâa-Tafilalet out of 12 Morocco regions was purposefully selected because of the ease of acquiring information regarding the list of cooperatives in the region. This is due, among other things, to the availability of the headquarters of the Tafilalt Agricultural Development 
Regional Office (TADRO) and good contacts within the research and extension personnel in the district. The purpose of this study is to analyze the effects of participation in agricultural cooperatives on the dynamic of youth entrepreneurship in rural areas. In order to achieve this objective, a survey was carried out with rural youth, both young men and young women, in the rural communities of the Drâa-Tafilalet region. These young people are members of agricultural cooperatives with several subjects of specific interest. They were approached with a questionnaire as well as by direct observation and were randomly chosen. Data collection was undertaken in 2020. Separate lists were compiled of rural young adult members of the relevant agricultural cooperatives selected for this study and those of the olive oil cooperatives were prepared with the help of community service officers, from the Departments of Provincial Directions of Agriculture, Agency for the Agricultural Development, National Initiative for Human Development, National Institute for Agronomic Research, Moroccan Office for the Development of Cooperation, Promotion of Employment and Skills, and the Tafilalt Agricultural Development Regional Office. A sample of 130 young people who were members of agricultural cooperatives covers more than ten cooperatives across six rural communities of the Drâa-Tafilalet region. We look at whether participation in collective entrepreneurship appears to promote entrepreneurial culture for the creation and management of new businesses by the rural youth, because the intention to start a business, especially in rural areas, is dependent on active participation and experience in agricultural cooperatives. We used the results of a field survey that aimed at analyzing entrepreneurial intentions of young members in all the agricultural cooperatives which participated in this research project.

In terms of the research questions, the study made use of the primary data which had been collected by means of a semi-structured questionnaire. The data that was collected through questionnaires are made up of socio-demographic details, attitude toward the entrepreneurial behavior, subjective norm, experience in the cooperative, and obstacles and barriers affecting entrepreneurial intention (Table 1). Once prepared, the questionnaires were discussed with extension officers and stakeholders; it was then pre-tested to ensure validity and reliability of the data that are to be collected. After the approval of the questionnaires, face-to-face interviews were conducted by the investigators with young rural members of agricultural cooperatives to generate all the data that were required. The questionnaires were mainly open-ended and closed questions written in French, but they were administered by the investigators, interpreting them into Arabic where there was a need.

\subsection{Selections of Variables and Their Measurements}

Analyzing entrepreneurial intentions with a binary logistic regression has been the approach adopted in numerous recent publications [13]. The interest of this study is in examining the factors that influence entrepreneurial intentions of young rural members of cooperatives. The dependent and independent variables were selected in the light of the objectives of the study and their measurement was done with the help of standard tools which were either already developed by researchers in the past or from certain schedules developed for the purpose. The variables of the study and their measurement are given in Table 1. The empirical analysis was developed using the process that involved asking young women and men, all members of agricultural cooperatives, for information through a questionnaire. Our greatest interest in this study was focused on the analysis of entrepreneurial intentions. 
Table 1. Variables introduced in the model with an expected sign on entrepreneurial intention.

\begin{tabular}{|c|c|c|c|}
\hline Variable Name & Nature of the Variable & Response/Variable Value & Sign \\
\hline \multicolumn{4}{|c|}{ Dependent variable } \\
\hline Entrepreneurial intention & Dichotomous & Yes $=1 / \mathrm{No}=0$ & + \\
\hline \multicolumn{4}{|c|}{ Independent variables } \\
\hline \multirow[t]{2}{*}{ Gender } & Dichotomous & Male $=1 /$ Female $=0$ & + \\
\hline & Dichotomous & $\mathrm{Yes}=1 / \mathrm{No}=0$ & \\
\hline Age & Numerical variable & $\begin{array}{l}\text { Age: exact age at time of interview, the } \\
\text { respondents were asked to provide their year } \\
\text { of birth }\end{array}$ & + \\
\hline Education level & Category variable & $\begin{array}{c}0=\text { Koranic, } 1=\text { Primary school, } 2=\text { Middle } \\
\text { school, and } 3=\text { Graduate degree }\end{array}$ & + \\
\hline Income other & Dichotomous & Yes $=1 / \mathrm{No}=0$ & \pm \\
\hline Youth status & Category variable & $0=$ Not working, $1=$ Farm hand, and $3=$ Other & \pm \\
\hline Agricultural cooperative & Category variable & $\begin{array}{c}1=\text { Medicinal and aromatic Plants } \\
2=\text { Agribusinesses }, \text { and } 3=\text { Animal production }\end{array}$ & \\
\hline Entrepreneurship_training & Dichotomous & Yes $=1 / \mathrm{No}=0$ & \pm \\
\hline Role_of_experience & Dichotomous & $\mathrm{Yes}=1 / \mathrm{No}=0$ & + \\
\hline Self_efficacy & Dichotomous & Yes $=1 / \mathrm{No}=0$ & + \\
\hline Financing_constraints & Dichotomous & $\mathrm{Yes}=1 / \mathrm{No}=0$ & - \\
\hline Risk_perception & Dichotomous & Yes $=1 / \mathrm{No}=0$ & - \\
\hline Entrepreneurial_opportunities & Dichotomous & $\mathrm{Yes}=1 / \mathrm{No}=0$ & + \\
\hline Start_business_rural_areas & Category variable & $\begin{array}{c}0=\text { Constraint, } 1=\text { Challenge } \\
\text { and } 2=\text { Opportunity }\end{array}$ & + \\
\hline
\end{tabular}

\subsection{Econometric Model}

IBM SPSS Statistics 22 was used to run a logistic regression to determine the probability factors that predict whether or not the youth will start a business within three years. The variables used in the econometric model are based on the empirical literature review. With logistic regression, the response variable is an indicator of some (binary) characteristics. Based on the logit transformation of the dependent variable, the binary logistic regression model quantifies the "odds" of the occurrence of an event. The outcome probabilities for each dependent variable value are the basis of the model [50].

Let $\pi$ be the probability of the occurrence of an event, then $1-\pi$ is the probability of its non-occurrence. Thus, the odds of the event are given by:

$$
\text { adds }=\frac{\pi}{1-\pi}
$$

The logit function based on a single predictor variable is defined as:

$$
\log \left(\frac{\pi}{1-\pi}\right)=\beta 0+\beta 1 x
$$

The general linear logistic model can be now written as:

$$
\log \text { it } \pi \mathrm{j}=\log \left(\frac{\pi}{1-\pi \mathrm{j}}\right)=\mathrm{X}_{\mathrm{J}}^{\mathrm{T}} \beta
$$


The logistic model is stated as:

$$
\log _{e}\left(\frac{p_{i}}{1-p_{i}}\right)=\alpha+\beta x i
$$

where

$\mathrm{X} \mathrm{i}$ is a vector of measurements corresponding to covariates and dummy variables corresponding to factor levels. The independent variables may be dichotomous, categorical, or continuous. The estimates of the parameters $\beta$ and consequently $\pi j$ are obtained by maximizing the log-likelihood function. The use of the binary logistic regression model here is to evaluate the probability of a high index for entrepreneurial intention of rural youth members of agricultural cooperatives surveyed in this study based on a set of explanatory variables (all dichotomous in nature, i.e., to estimate $P(Y=1 / \dot{X})$ where $\dot{X}$ is the known vector of explanatory variables).

\section{Results}

\subsection{Descriptive Analysis}

Descriptive analysis was used to characterize and understand the socio-economic profile of the young men and women members of cooperatives. Descriptive statistics included age, gender, level of education, and youth status. Table 2 presents the demographics of the respondents of the study. The response group consisted of $130(46.2 \%)$ female respondents and 113 (53.8\%) male respondents. Fifty-four (41.54\%) responded by saying that they intended to start a business within three years, while $76(58.46 \%)$ were not thinking about individual business units. Based on the results, 51 (85\%) female respondents have a strong preference for collective entrepreneurship; nine (15\%) of them announced their intention to create a new business venture; and 45 (64.27\%) of the male respondents showed a high agreement with the entrepreneurial culture through self-employment. Of 70 male respondents, $35.72 \%$ of them did not think of self-employment. On a whole, men were found to be more strongly interested in starting a business than females. Age has a minimum value of 20 and a maximum value of 45 , with the cumulative percentage $(66.92 \%)$ of the respondents within the age bracket of 20-40 years. This was followed by $33.08 \%$, representing the age group of 40-45 years. Level of education showed that $44.6 \%$ of the respondents had no schooling (Koranic) and $16.2 \%$ had only primary education. Secondary school was completed by $27(7 \%) ; 11.5 \%$ received a university degree. In addition to their membership in cooperatives, we found that the majority of our sample youth $(81 \%)$ engaged in various informal sector activities, while $23.1 \%$ were farm hands and $14.6 \%$ were traders. The membership rates of the respondents are presented in Table 3. The major activities of the agricultural cooperatives were (I) medicinal and aromatic plants (40.8\% for the entire group of respondents); (II) agribusinesses (34.6\% for all respondents); and (III) livestock (24.6\% for the whole group of respondents).

Table 4 indicates the results of descriptive statistics regarding rural youth's perspectives about entrepreneurial intention; the male/female distribution among respondents was fairly balanced (male 53.8\%, female 46.2\%). Hereby, respondents generally show different personal attitude. In the data of the study, it was observed that $41.54 \%$ responded by saying that they intended to start a business within three years, while $58.46 \%$ were not thinking about individual business units. The results described that males are led inclined to be an entrepreneur than women. Young male members of cooperatives with positive entrepreneurial intentions $83.4 \%$ compared to $16.6 \%$ for women. According to the result of major activities of the agricultural cooperatives, it can be observed that the willingness of respondents to start the business creation is $55.5 \%$ for members of the medicinal and aromatic plants, $31.5 \%$ agribusinesses cooperatives, and $13 \%$ for livestock cooperatives. 
Table 2. Demographics of the sample.

\begin{tabular}{cccc}
\hline Variables & Frequency & Percentage & Cumulative Percentage \\
\hline Gender & 60 & & \\
Female & 70 & 46.2 & 46.2 \\
Male & 130 & 53.8 & 100 \\
Total number of observations & & & \\
\hline Level of education & 58 & 44.6 & 44.6 \\
Koranic & 21 & 16.2 & 60.8 \\
Primary school & 36 & 27.7 & 100 \\
Middle school & 15 & 11.5 & \\
Graduate degree & 130 & & 8.46 \\
Total number of observations & & & 23.08 \\
\hline Age & 11 & 8.46 & 61.54 \\
20-25 & 19 & 14.62 & 100.00 \\
26-30 & 37 & 28.46 & \\
$31-35$ & 20 & 15.38 & 23.1 \\
$36-40$ & 43 & 33.08 & 37.7 \\
$41-45$ & & & 100 \\
\hline Youth status & 30 & 23.1 & \\
Farm hand & 19 & 62.3 & \\
Trader & 81 & & \\
Other & & &
\end{tabular}

Source: Field survey, 2020.

Table 3. Cooperatives' activities.

\begin{tabular}{cccc}
\hline Variables & Frequency & Percentage & Cumulative Percentage \\
\hline Cooperatives' activities & & & \\
Medicinal and aromatic plants & 53 & 40.8 & 40.8 \\
Agribusinesses & 45 & 34.6 & 75.4 \\
Livestock & 32 & 24.6 & 100.0 \\
& 130 & & \\
\hline
\end{tabular}

Table 4. Descriptive statistics by entrepreneurial intention.

\begin{tabular}{cccc}
\hline Variables & Total Sample & \multicolumn{2}{c}{ Entrepreneurial Intention } \\
\cline { 3 - 4 } & $(\mathbf{N}=\mathbf{1 3 0 )}$ & Yes $\mathbf{( N = 5 4 )}$ & No (N = 76) \\
\hline Gender & & & \\
Female & $60(46.2 \%)$ & $9(16.6 \%)$ & $51(67.1 \%)$ \\
Male & $70(53.8 \%)$ & $45(83.4 \%)$ & $25(32.9 \%)$ \\
Total number of observations & 130 & 54 & 76 \\
Cooperative's activities & & & \\
Medicinal and aromatic plants & $53(40.7 \%)$ & $30(55.5 \%)$ & $23(30.4 \%)$ \\
Agribusinesses & $45(34.6 \%)$ & $17(31.5 \%)$ & $28(36.8 \%)$ \\
Livestock & $32(24.7 \%)$ & $7(13 \%)$ & $25(32.8 \%)$ \\
Total number of observations & 130 & 54 & 76 \\
Education & & & \\
Primary school & $77(59.3 \%)$ & $26(48.2 \%)$ & $51(67.1 \%)$ \\
Middle school & $38(29.2 \%)$ & $25(46.3 \%)$ & $13(17.1 \%)$ \\
Graduate degree & $15(11.5 \%)$ & $3(5.5 \%)$ & $12(15.8 \%)$ \\
Total number of observations & 130 & 54 & 76 \\
Youth status & & & \\
Farm hand & $30(23.1 \%)$ & $14(25.9 \%)$ & $16(21 \%)$ \\
Trader & $19(14.6 \%)$ & $13(24.1 \%)$ & $6(8 \%)$ \\
Other & $81(62.3 \%)$ & $27(50 \%)$ & $54(71 \%)$ \\
Total number of observations & 130 & 54 & 76 \\
\hline
\end{tabular}




\subsection{Interpretation of the Results of Binary Logistic Regression}

Table 5 shows the results of the binary logistic regression of perceptions that may be affecting the individual's entrepreneurial intention. Logistic regression is used to identify significant variables that help to estimate the likelihood of an individual's intention to start a business within three years. Independent variables predict entrepreneurial intention from socio-demographic variables and individual perceptions, and activities of the cooperative show that age, gender, level of education of young adult members of cooperatives, level of education, and individual perceptions are statistically significant. Financing constraints, risk perception, entrepreneurial opportunities in rural areas, cooperatives' activities, and the experience of young people in agricultural cooperatives are also statistically significant predictors. Model 1 is the basic model including only variables related to socio-demographic characteristics. Regarding gender, males are 75,848 times more likely than females to declare a positive intention (odds ratio). Paradoxically, a higher education level is associated with weak intentions, with odds ratios ranging from 1.417 to 0.184 . For every young adult member with an annual income, the odds of a positive intention (versus no intention) increased by a factor of 2.160. The effect of income is positive because having another source of income is associated with positive entrepreneurial intentions. Thus, Model 2 shows that entrepreneurial opportunities are the strongest determinant of entrepreneurial intention, having $5 \%$ confidence for an odds ratio of 18.761. Financing constraints are the second strongest determinant since the odds ratio accounts for 13.608. Similarly, entrepreneurship with an odds ratio of 5.595, training, experience (4.093), and self-efficacy (3.173) positively influences entrepreneurial intentions. For Model 3, the subject cooperatives are divided into medicinal and aromatic plants; agribusinesses; and animal production. Activities of the cooperative can significantly affect the individual's entrepreneurial intention. They are also associated with the explanation of entrepreneurial intention among the young rural members of agricultural cooperatives and should therefore be accounted for when the main model is designed.

In the results of the binary logistic regression for the factors in the final model (Model 4) as displayed in Table 5, the variables that were found to be significant in the multivariate analysis are cooperatives' activities, level of education, age, financing constraints, entrepreneurship training, income from other sources, the role of experience in the agricultural cooperative, risk perception, and entrepreneurial opportunities in rural areas. Moreover, this is in line with the results obtained from the univariate analysis. The values of the Wald statistic for individual $\beta$ coefficients support that the estimated values $(\beta)$ are significantly different from zero at $\alpha=0.05$ level of significance for all the above-selected factors. The final logistic regression model includes only those significant variables. From the fitted logistic regression model, the estimates' odds ratios are displayed in Table 5. In Model 5, entrepreneurial intentions are predicted by age, income from other sources, entrepreneurship training, the role of experience, financing constraints, risk perception, and entrepreneurial opportunities with the odds ratios of $0.814,12.12,1.419,0.318$, and 9.1041 per unit increase of variables, respectively. A strong awareness of the business opportunities for youth in rural areas increases the odds of a high entrepreneurial intention to 9.041. Logistic regression used to predict barriers to the development of the entrepreneurial culture shows that the beta values of the financing constraints and risk perception variables are significantly different from zero $(p<0.05)$. Financing constraints for entrepreneurship show the greatest impact for a low intention of entrepreneurship (odds ratio of 0.042). The risk of failure in entrepreneurship and of perception decreases the odds of a positive entrepreneurial intention to 0.318 . The analysis also shows that activities of the cooperative are significant $(p<0.05)$. A young adult who hails from an agribusinesses cooperative increases the odds of positive intention being rated at one by 4.658 . The odds of a high index for entrepreneurial intention are $365.8 \%$ times higher for a young adult from an agribusiness cooperative in relation to a medicinal and aromatic plants cooperative. Similarly, there is a greater probability of starting a business for a young member of a livestock cooperative; the odds of a positive intention are increased by a factor of 2.168 compared to that of a young person who is a member of a medicinal and aromatic plants cooperative. 
Table 5. Results of binary logistic regression models.

\begin{tabular}{|c|c|c|}
\hline \multicolumn{3}{|c|}{ Model 1} \\
\hline & B & Odds ratio \\
\hline \multicolumn{3}{|l|}{ Socio-demographic variables } \\
\hline Age & $-0.203^{* * *}$ & 0.816 \\
\hline Gender (1) & $4.329 * * *$ & 75.848 \\
\hline Education & ** & \\
\hline Education (1) & $0.348^{* *}$ & 1.417 \\
\hline Education (2) & $-1.691 * *$ & 0.184 \\
\hline Income_other (1) & 0.770 * & 2.160 \\
\hline Youth_status & $* * *$ & \\
\hline Youth status (1) & $-0.438^{* * *}$ & 0.645 \\
\hline Youth status (2) & $2.095^{* * *}$ & 8.125 \\
\hline Constant & $2.709 * *$ & 15.009 \\
\hline \multicolumn{3}{|c|}{ Model 2} \\
\hline Individual perceptions & $\mathrm{B}$ & $\operatorname{Exp}(\mathrm{B})$ \\
\hline Entrepreneurship training (1) & $1.722 * * *$ & 5.595 \\
\hline Role of experience (1) & $1.409 * *$ & 4.093 \\
\hline Self-efficacy (1) & $1.155^{* *}$ & 3.173 \\
\hline Financing constraints (1) & $2.611^{* * *}$ & 13.608 \\
\hline Risk perception (1) & $0.283^{* *}$ & 1.326 \\
\hline Entrepreneurial opportunities (1) & $2.932 * * *$ & 18.761 \\
\hline Constant & $-5.517^{* * *}$ & 0.004 \\
\hline \multicolumn{3}{|c|}{ Model 3} \\
\hline Activities of the cooperative & $\mathrm{B}$ & Odds ratio \\
\hline Medicinal and aromatic plants & $* * *$ & \\
\hline Agribusinesses & $1.539^{* * *}$ & 4.658 \\
\hline Livestock & $0.774^{* *}$ & 2.168 \\
\hline Constant & $-1.273^{* * *}$ & 0.280 \\
\hline \multicolumn{3}{|c|}{ Model 4} \\
\hline & B & Odds ratio \\
\hline \multicolumn{3}{|l|}{$\begin{array}{l}\text { Socio-demographic } \\
\text { variables }\end{array}$} \\
\hline Age & $-0.206^{* * *}$ & 0.814 \\
\hline Education & $* * *$ & \\
\hline Education (1) & $0.832 * * *$ & 2.299 \\
\hline Education (2) & $1.162 * * *$ & 3.196 \\
\hline Income other (1) & $2.495^{* * *}$ & 12.120 \\
\hline \multicolumn{3}{|l|}{$\begin{array}{l}\text { Individual } \\
\text { perceptions }\end{array}$} \\
\hline $\begin{array}{l}\text { Entrepreneurship } \\
\text { training (1) }\end{array}$ & $0.350 * *$ & 1.419 \\
\hline Role of experience (1) & $1.437^{* *}$ & 4.207 \\
\hline $\begin{array}{l}\text { Financing constraints } \\
\text { (1) }\end{array}$ & $-3.182^{* * *}$ & 0.042 \\
\hline Risk perception (1) & $-1.144^{* *}$ & 0.318 \\
\hline $\begin{array}{l}\text { Entrepreneurial } \\
\text { opportunities (1) }\end{array}$ & $2.202 * * *$ & 9.041 \\
\hline \multicolumn{3}{|l|}{$\begin{array}{c}\text { Activities of the } \\
\text { cooperative }\end{array}$} \\
\hline \multicolumn{3}{|l|}{ Agribusinesses } \\
\hline Livestock & $-1.402^{* *}$ & 0.246 \\
\hline $\begin{array}{l}\text { Medicinal and } \\
\text { aromatic plants }\end{array}$ & $-1.738^{* *}$ & 0.176 \\
\hline Constant & $5.490 * * *$ & 242.159 \\
\hline
\end{tabular}

$\overline{* * *}$, significant at $p<0.001 ;{ }^{* *}$, significant at $p<0.01$; and ${ }^{*}$, significant at $p<0.05$. 
From Table 5, hypotheses H1a and H1b are confirmed. The result of the logit depicts that the personal and socio-economic variables will exert a positive effect on entrepreneurial intentions. This is explainable by the fact that most older youth are experienced or were more likely to come from professional areas and thus desire to realize something worthwhile for themselves, therefore being more likely to become self-employed entrepreneurs, supporting hypothesis H1. Second hypothesis H2 is also confirmed; what this means is that participation in agricultural cooperatives substantially enhances entrepreneurial intentions among the rural youth. The longer the duration of one's membership as a young member of an agricultural cooperative, the more likely the chances of a youth becoming a rural entrepreneur; this also confirms hypothesis $\mathrm{H} 2 \mathrm{a}$. In other words, work experience within agricultural cooperatives positively influences entrepreneurial intentions. Third, hypothesis $\mathrm{H} 3$ is also confirmed because, at a $5 \%$ significance level, the factors which characterize the rural environment influence the entrepreneurial intention of the youth.

Table 6 presents the maximum likelihood estimates of the factors that influence entrepreneurial intention for the youth and the women members of cooperatives. Nagelkerke's R-squared shows that Model 4 explains about $87 \%$ of the variation in the outcome variable (probability of starting a business within three years). Additionally, in Model 2, a chi-square value of 0.830 , indicating that the likelihood ratio statistics are highly significant $(p<0.000)$, suggests that the overall model had a strong explanatory power. In general, -2 log-likelihood is a measure of badness-of-fit, illustrating error remaining in the model after accounting for all independent variables. The -2LL of 92.605 in Model 1; 51.939 in Model 2; 165.834 in Model 3; and 41.437 in Model 4 indicates that there are no significant errors remaining.

Table 6. Models summary.

\begin{tabular}{cccc}
\hline Model & $\mathbf{- 2}$ Log-Likelihood & Cox and Snell's R-Squared & Nagelkerke's R-Squared \\
\hline 1 & $92.605^{\mathrm{a}}$ & 0.475 & 0.640 \\
2 & $51.939^{\mathrm{a}}$ & 0.616 & 0.830 \\
3 & $165.834^{\mathrm{a}}$ & 0.079 & 0.106 \\
4 & $41.437^{\mathrm{a}}$ & 0.646 & 0.870 \\
\hline
\end{tabular}

a Estimation terminated at iteration number 8 because parameter estimates changed by less than 0.001 .

\section{Discussion and Conclusions}

As the introduction to this paper pointed out, research on entrepreneurship intention and African rural youth has experienced some progress over the last few years. However, the actual outcomes of entrepreneurship on rural development are largely unknown. Against this background, the paper's approach to entrepreneurship intention is very important not only at the individual level but also at the level of associational activity. Specifically, the first important contribution was made by providing classification on the different perceptions related to entrepreneurial intentions. This paper examined the determinants relating to entrepreneurial intentions of rural youth, and classified the factors influencing the choice or decision-making between permanent membership at the cooperative and an entrepreneurial career choice among rural youth. It also identified groups that have been neglected in prior studies and highlighted areas where further research is required. The results have been very promising, but it is necessary to adopt enterprise and encourage job creation in new efficient employment strategies. The findings of this study illustrate that entrepreneurial intention is significantly superior among those of the masculine gender who have no degree. Graduates who opt for such employment opportunities prefer instead to explore employment possibilities in the public sector and foreign countries. The entrepreneurial spirit in young graduates has long been a question of great interest in a wide range of fields. A similar study carried out on entrepreneurship education for graduates indicated that there is a mismatch between education and the type of employment opportunities available in the labor market [26]. 
The findings of this study show that gender differences in entrepreneurial intentions had a significant impact on starting a business. The results of this survey indicate that the effect of gender is mediated via social norms that characterize rural environments. The agricultural cooperative is an increasingly important activity in rural areas; it is a collective, solidarity activity where rural women voluntary and joyfully collaborate for the actualization of a socio-economic and community project for income-generating activity. The cooperative aims at providing a supportive environment that rural women can use to maintain family stability and security, but is often not a question of choice but a function of a lack of other options. Young male members of cooperatives with positive entrepreneurial intentions $(83.4 \%)$ were more likely to have more precise intentions to start a business, vis-à-vis their female counterparts $(16.6 \%)$. This finding corresponds with the results of a study on gender differences in entrepreneurial intentions [51]. The effect of gender on entrepreneurial intentions is mediated via personal attitudes and perceived behavioral control but not social norms [51].

In addition, the age in a group of young adult members of cooperatives is a statistically significant variable that can affect entrepreneurial intentions. As age increases, positive entrepreneurial intentions regularly decrease. Young people aged between 41 and 45 years are attached to their cooperatives, and less likely to start a new business venture than young people between 20 and 25. A similar study also shows that as employees age, they are less inclined to act entrepreneurially, and their entrepreneurial intention is lower the more they identify with their job [52]. However, these results contradict the results established by the authors of [52]. These authors assert that the older youth members easily access factors of production, particularly human, social, and financial capital, while younger people may lack experience in running companies, marketing, human resources, sales, sectorspecific knowledge regarding customers' needs, strategic opportunities, and regulatory constraints. Entrepreneurial training, entrepreneurial opportunities, and having experience in cooperatives seem to have a positive impact on the entrepreneurial intentions of young women and men who are members of agricultural cooperatives. A similar study suggests that individuals with an entrepreneurial background were more likely than others to start a new business venture because they had obtained competence, sufficient experience, and self-confidence [53].

For the barriers facing the youth choosing to embark on entrepreneurship, we have found significant direct relationships with financing constraints, risk perception, and entrepreneurial intention. The survey also shows that the main hindrances to positive entrepreneurial intentions for many youth members of cooperatives result from the lack of access to funding and the complexity of the financial assistance system. However, lack of collateral prevents many young adults from obtaining financial assistance from financial institutions. Similarly, Ref. [54] noted that, to start a business, a young person needs several sources of funding, including debt financing, government subsidies, and self-financing. Study [55] also highlighted that, to turn their dream into reality, an individual needs to overcome difficulties in accessing finance. Lack of finance is an obstacle that affects the preferred future career choice of the youth because of financial constraints [56]. In addition, the dominance of economic uncertainty in rural areas can also negatively influence those that wish to start their businesses. Moreover, young people's risk of failure in business objectives would increase because adverse and volatile commodity prices, climatic risk, and rural vulnerability affect both entrepreneurship intention and youth engagement in rural economic activities, creating uncertainty in sustainable farm income and the capacity of the youth to develop the entrepreneurial spirit.

There are reasons to believe that entrepreneurial intention in youth cooperatives and the future of rural entrepreneurship are linked. Regarding organizational structure, many of the financing actions for cooperatives are through unallocated equity capital and state subsidies. There have been instances of members being driven less by a wish to involve themselves in the ongoing development of cooperative activities. On the contrary, they are inclined to seek free-riding behavior, as well as avoid investing in the cooperative [56]. 
The authors of [57] evaluated the determinants of students' preferences of agricultural sub-sector engagement in Cameroon. Their results show that improving the attractiveness of, and working conditions in, the agricultural sector could increase youth engagement in agribusiness and rural economic activities. Thus, the necessity of sustainable entrepreneurship, the detection of effective factors to promote self-employment, and the identification of barriers to entrepreneurship in rural areas will be key sources of security as well as social stability of the country and will also strengthen investment and job creation. How policymakers address these and other challenges to youth engagement in rural economic activities and agribusiness in Morocco will shape the extent to which rural entrepreneurship can play a crucial role in helping young people enter the labor market, reduce poverty, migration, economic disparity, and unemployment, in addition to developing rural areas.

\section{Implications for Policy Development}

As a result of the dominance of social entrepreneurial ventures and the substantial interest of policymakers to reinforce collective strategy, particularly in rural areas, an increasing number of researchers are focusing on individual entrepreneurs and often characterizing them as major tools for combating youth unemployment. Agricultural cooperatives are among the many manifestations of collective action and represent another form of rural projects for young entrepreneurs in Morocco. Nevertheless, unlike strong collective actions, private initiatives are weak in agribusiness and rural economic activities. Based on the results of this study, the following implications for policy development can be drawn.

Widening and diversifying the sources of funding for rural entrepreneurship: unavailability of finance is one of the biggest constraints that the rural youth are bearing nowadays, especially due to the absence of specific credit for youth businesses and tangible security. We must remove these barriers that prevent young people from engaging in agribusiness and rural economic activities. Further efforts are needed to improve the business environment as well as access to finance. The State must intervene to force banks to develop risky activities and engage them in agriculture and rural development.

Entrepreneurship education: the low level of entrepreneurship education of rural youth and the lack of access to technologies and market information should make us stop and think. These are factors that place rural entrepreneurship at a disadvantage. This has also led to a challenge of lack of technical knowledge, because their awareness of their deficient knowledge makes them less confident in their ability to succeed in starting a business. In doing so, they will need support. A training policy framework aimed at the rural youth based on the real needs of future entrepreneurs should be implemented. Regarding topics to be included in training programs, rural youth have expressed interest in issues such as (I) collaborative leadership for sustainable change; (II) entrepreneurship and innovation; (III) business plans; (IV) a participatory approach and rural development and (V) the provision of targeted, program-specific information, awareness-raising activities, advice, assistance, and training to dismantle administrative barriers to business operation and creation.

Rural women should be encouraged to take up entrepreneurship as a career. Among the challenges facing rural women, traditions and customs which characterize rural society, the family environment, and less access than men to education and training have adverse consequences for their entrepreneurial intentions. This indicates a need to mobilize the Government, all relevant actors, and organizations to reinforce female entrepreneurship to give rural women the place they deserve in rural development, by allowing them to increase their rate of business ownership. Lastly, policymakers must provide constant support of rural women by formulating and implementing a support strategy for transferring knowledge and skills surrounding entrepreneurship in the agri-food sector.

Youth access to land: the youth, with their ability to identify the opportunities offered in rural areas, have been blocked by land tenure. Therefore, access to land, its use, and the enhancement of agriculture are factors contributing to the emergence of the new generation 
of young entrepreneurs. The State should facilitate their access to land by a profound reform of the land tenure system. This must become a land policy priority in its own right, given the impact of rural depopulation for the future of rural entrepreneurship.

Major implication for academicians: this research provides considerable insight into the entrepreneurial intention among rural youth in agricultural cooperatives; it identified the determinants of entrepreneurial intention among Moroccan youth in rural areas. These findings, presented in this paper, suggest directions in the field of entrepreneurial intention (EI), and provide better information about rural youth members of the cooperatives, their entrepreneurial motivations, and the nature of their issues regarding new venture creation. Furthermore, this research also highlights the major interest of rural entrepreneurship research in in Morocco and other African countries. Though a few researchers have ventured into exploratory studies of different regions (see, for example, $[2,5,12,17,27]$ ), a lack exists regarding the factors influencing youths' entrepreneurial intentions. This study could constitute a new research orientation, to stimulate the production of scientific knowledge. In summary, we can definitely state that they are many research areas within the field of rural entrepreneurship which are yet to be explored to the fullest.

Author Contributions: Conceptualization, A.F. and E.H.B.; Data curation, E.H.B.; Formal analysis, E.H.B. and K.A.; Investigation, E.H.B.; Methodology, T.A., K.A. and A.F.; Supervision, T.A. and K.A.; Validation, K.A.; Visualization, A.B.; Writing-original draft, E.H.B. All authors have read and agreed to the published version of the manuscript.

Funding: This research is funded by the International Fund for Agricultural Development (IFAD) under the Research Fellowship "Enhancing Capacity to Apply Research Evidence (CARE) in Policy for Youth Engagement in Agribusiness and Rural Economic Activities in Africa". Project in the International Institute of Tropical Agriculture (IITA).

Institutional Review Board Statement: Not applicable.

Informed Consent Statement: Informed consent was obtained from all subjects involved in the study.

Data Availability Statement: Not applicable.

Acknowledgments: A special word of thanks to IITA's Communications and Information Services staff for editing this manuscript.

Conflicts of Interest: The authors confirm that there is no conflict of interest.

\section{References}

1. Boateng, G.O.; Boateng, A.A.; Bampoe, H.S. Barriers to youthful entrepreneurship in rural areas of Ghana. Glob. J. Bus. Res. 2014, 8, 109-119.

2. Malebana, J. Entrepreneurial intentions of South African rural university students: A test of the theory of planned behaviour. J. Econ. Behav. Stud. 2014, 6, 130-143. [CrossRef]

3. Sumberg, J.; Hunt, S. Are African rural youth innovative? Claims, evidence and implications. J. Rural Stud. 2019, 69, 130-136. [CrossRef]

4. Odumosu, A.A.; Binuyo, A.O.; Adefulu, A.D.; Asikhia, O.U. Social innovation and graduate entrepreneurship in Nigeria. IOSR J. Bus. Manag. 2020, 22, 48-55.

5. Ataei, P.; Karimi, H.; Ghadermarzi, H.; Norouzi, A. A conceptual model of entrepreneurial competencies and their impacts on rural youth's intention to launch SMEs. J. Rural Stud. 2020, 75, 185-195. [CrossRef]

6. Cornia, G.A.; Deotti, L.; Sassi, M. Sources of food price volatility and child malnutrition in Niger and Malawi. Food Policy 2016, 60, 20-30. [CrossRef]

7. Elattir, M.; Allame, Y.K.; Tihm, Y. Women's economic empowerment in Morocco: The case of social entrepreneurship. In Women's Movements in Post-"Arab Spring" North Africa; Palgrave Macmillan: New York, NY, USA, 2016; pp. 283-298. [CrossRef]

8. Venâncio, A.; Pinto, I. Type of Entrepreneurial Activity and Sustainable Development Goals. Sustainability 2020, $12,9368$. [CrossRef]

9. Boyer, T.; Blazy, R. Born to be alive? The survival of innovative and non-innovative French micro-start-ups. Small Bus. Econ. 2013, 42, 669-683. [CrossRef]

10. El Houssain, B.; Fadlaoui, A.; Allali, K.; Arrach, R. Contract Farming in the Morocco Cereal Sector: Contract Clauses, Ambiguity, and Opportunism. Int. J. Agric. Econ. 2019, 4, 245. [CrossRef] 
11. Aceytuno, M.-T.; Celia, S.-L.; de Paz-Báñez, M.A. Rising inequality and entrepreneurship during economic downturn: An analysis of opportunity and necessity entrepreneurship in Spain. Sustainability 2020, 12, 4540. [CrossRef]

12. Ridha, R.N.; Burhanuddin, B.; Wahyu, B.P. Entrepreneurship intention in agricultural sector of young generation in Indonesia. Asia Pac. J. Innov. Entrep. 2017, 11, 76-89. [CrossRef]

13. Liñán, F.; Rodríguez-Cohard, J.C.; Rueda-Cantuche, J.M. Factors affecting entrepreneurial intention levels: A role for education. Int. Entrep. Manag. J. 2011, 7, 195-218. [CrossRef]

14. Krueger, N.F., Jr.; Reilly, M.D.; Carsrud, A.L. Competing models of entrepreneurial intentions. J. Bus. Ventur. 2000, 6, 411-432. [CrossRef]

15. Davidsson, P. Determinants of entrepreneurial intentions. In Proceedings of the RENT XI Workshop, Piacenza, Italy, 23-24 November 1995; Volume 11, pp. 23-24.

16. Shane, S. Prior Knowledge and the Discovery of Entrepreneurial Opportunities. Organ. Sci. 2000, 11, 448-469. [CrossRef]

17. Nguyen, A.T.; Do, T.H.H.; Vu, T.B.T.; Dang, K.A.; Nguyen, H.L. Factors affecting entrepreneurial intentions among youths in Vietnam. Child. Youth Serv. Rev. 2019, 99, 186-193. [CrossRef]

18. Ortmann, G.F.; King, R.P. Agricultural Cooperatives I: History, Theory and Problems. Agrekon 2007, 46, 18-46. [CrossRef]

19. Zhong, Z.; Zhang, C.; Jia, F.; Bijman, J. Vertical coordination and cooperative member benefits: Case studies of four dairy farmers' cooperatives in China. J. Clean. Prod. 2018, 172, 2266-2277. [CrossRef]

20. Feng, L.; Hendrikse, G. Coordination and governance: The case of cooperatives versus IOFs. In Proceedings of the EAAE 2011 Congress-Change and Uncertainty, Zurich, Switzerland, 30 August-2 September 2011.

21. Hamdouch, B.; Wahba, J. Return migration and entrepreneurship in Morocco. Middle East Dev. J. 2015, 7, 129-148. [CrossRef]

22. Yami, M.; Feleke, S.; Abdoulaye, T.; Alene, A.D.; Bamba, Z.; Manyong, V. African Rural Youth Engagement in Agribusiness: Achievements, Limitations, and Lessons. Sustainability 2019, 11, 185. [CrossRef]

23. Haut-Commissariat au Plan Maroc, Indices Statistiques. Available online: https://www.hcp.ma/Indices-statistiques_r102.html (accessed on 15 November 2020).

24. Ministère de l'Economie et des Finances. Available online: https://www.finances.gov.ma/Publication/daag/2020 /PresentationMLM\%20du\%20FAFE\%20VF.pdf (accessed on 25 November 2020).

25. Kingdom of Morocco, Business Support and Financing Program: 'Intelaka' Program Launched. Available online: https:/ /www. maroc.ma/en/news/business-support-and-financing-program-intelaka-program-launched (accessed on 18 November 2020).

26. Vardhan, J.; Biju, S. A binary logistic regression model for entrepreneurial motivation among university students-A UAE perspective. J. Educ. Soc. Res. 2012, 2, 75.

27. Fenech, R.; Baguant, P.; Ivanov, D. Entrepreneurial attitudes, self-efficacy, and subjective norms amongst female Emirati entrepreneurs. Int. J. Entrep. 2019, 23, 1-11.

28. Zaremohzzabieh, Z.; Abu Samah, B.; Muhammad, M.; Omar, S.Z.; Bolong, J.; Shaffril, H.A.M. An investigation into factors influencing rural youth entrepreneurs' intentions to use ICT: A case of Malaysia. Int. J. Entrep. Small Bus. 2016, 27, 480. [CrossRef]

29. Dinc, M.S.; Budic, S. The Impact of Personal Attitude, Subjective Norm, and Perceived Behavioural Control on Entrepreneurial Intentions of Women. Eurasian J. Bus. Econ. 2016, 9, 23-35. [CrossRef]

30. Ajzen, I. The theory of planned behavior. Organ. Behav. Hum. Decis. Process. 1991, 50, 179-211. [CrossRef]

31. Sharma, L. Entrepreneurial intentions and perceived barriers to entrepreneurship among youth in Uttarakhand state of India. Int. J. Gend. Entrep. 2018, 10, 243-269. [CrossRef]

32. Adebayo, G.S.; Kavoos, M. The present attitude of African youth towards entrepreneurship. Int. J. Small Bus. Entrep. Res. 2016, 4, 21-38.

33. Zampetakis, L.A.; Anagnosti, A.; Rozakis, S. Understanding entrepreneurial intentions of students in agriculture and related sciences. In Proceedings of the EEAE 2014 Congress Agri-Food and Rural Innovations for Healthier Societies, Ljubljana, Slovenia, 26-29 August 2014.

34. Chatterjee, S.; Debabrata, D. Entrepreneurial Ability and Development of Micro Enterprise. Arthaniti J. Econ. Theory Pract. 2020. [CrossRef]

35. Soleymani, A.; Farani, A.Y.; Karimi, S.; Azadi, H.; Nadiri, H.; Scheffran, J. Identifying sustainable rural entrepreneurship indicators in the Iranian context. J. Clean. Prod. 2020, 290, 125186. [CrossRef]

36. Chavez, J. The Personality Characteristics of an Entrepreneur and Their Effects on the Performance of a New Business Venture. 2016. Available online: https:/ / www.theseus.fi/bitstream/handle/10024/112781/Chavez_Juuli.pdf?sequence=1\&isAllowed=y (accessed on 28 December 2020).

37. Brixiová, Z.; Kangoye, T. Gender and constraints to entrepreneurship in Africa: New evidence from Swaziland. J. Bus. Ventur. Insights 2016, 5, 1-8. [CrossRef]

38. Bowen, D.D.; Hisrich, R.D. The female entrepreneur: A career development perspective. Acad. Manag. Rev. 1986, 11, 393-407. [CrossRef]

39. Cromie, S. Motivations of aspiring male and female entrepreneurs. J. Organ. Behav. 1987, 8, 251-261. [CrossRef]

40. Thorgren, S.; Sirén, C.; Nordström, C.; Wincent, J. Hybrid entrepreneurs' second-step choice: The nonlinear relationship between age and intention to enter full-time entrepreneurship. J. Bus. Ventur. Insights 2016, 5, 14-18. [CrossRef]

41. Douglass, M.E. Relating education to entrepreneurial success. Bus. Horizons 1976, 19, 40-44. [CrossRef] 
42. Meoli, A.; Fini, R.; Sobrero, M.; Wiklund, J. How entrepreneurial intentions influence entrepreneurial career choices: The moderating influence of social context. J. Bus. Ventur. 2019, 35, 105982. [CrossRef]

43. Tay, R.S. Degree of Entrepreneurship: An Econometric Analysis Using the Ordinal Probit Model. J. Small Bus. Entrep. 1998, 15, 83.

44. Udimal, T.B.; Luo, M.; Liu, E.; Mensah, N.O. How has formal institutions influenced opportunity and necessity entrepreneurship? The case of brics economies. Heliyon 2020, 6, e04931. [CrossRef] [PubMed]

45. Dahalan, N.; Jaafar, M.; Rosdi, S.A.M. Local Community Readiness in Entrepreneurship: Do Gender Differ in Searching Business Opportunity. Procedia Soc. Behav. Sci. 2013, 91, 403-410. [CrossRef]

46. Corbett, A.C. Experiential Learning within the Process of Opportunity Identification and Exploitation. Entrep. Theory Pract. 2005, 29, 473-491. [CrossRef]

47. Haut-Commissariat au Plan Maroc, Présentation de la Région Draa. Available online: https://www.hcp.ma/draa-tafilalet/ Presentation-de-la-region-de-Draa-Tafilalet_a4.html (accessed on 5 November 2020).

48. Centre Régional d'Investissement Drâa Tafilalet. Available online: https://draatafilaletinvest.com/en/home/ (accessed on 8 December 2020).

49. Moroccan Office for the Development of Cooperation (ODCO). Available online: http://www.odco.gov.ma/fr/content/coop\% C3\%A9ratives-au-maroc (accessed on 8 December 2020).

50. Naong, M.N. Promotion of Entrepreneurship Education-A Remedy to Graduates and Youth Unemployment-A Theoretical Perspective. J. Soc. Sci. 2011, 28, 181-189. [CrossRef]

51. Maes, J.; Leroy, H.; Sels, L. Gender differences in entrepreneurial intentions: A TPB multi-group analysis at factor and indicator level. Eur. Manag. J. 2014, 32, 784-794. [CrossRef]

52. Hatak, I.; Harms, R.; Fink, M. Age, job identification, and entrepreneurial intention. J. Manag. Psychol. 2015, 30, 38-53. [CrossRef]

53. Azoulay, P.; Jones, B.F.; Kim, J.D.; Miranda, J. Age and High-Growth Entrepreneurship. Am. Econ. Rev. Insights 2020, 2, 65-82. [CrossRef]

54. Deakins, D.; North, D. SMEs' Access to Finance: Is There Still a Debt Finance Gap. Inst. Small Bus. Entrep. 2008, 24, 147-159.

55. Nengomasha, M.C. Entrepreneurial Intentions and Perceived Access to Finance: The Role of Entrepreneurial Self-Efficacy. Master's Thesis, University of the Free State, Bloemfontein, South Africa, 2018.

56. National Credit Regulator (NCR). Literature Review on Small and Medium Enterprises' Access to Credit and Support in South Africa. 2011. Available online: https:/ /www.smallbusinessinstitute.co.za/wp-content/uploads/2019/12/NCRLiteratureReview-on-SME-Access-to-Credit-in-South-Africa_Final-Report_NCR_Dec-2011.pdf (accessed on 7 November 2020).

57. Mkong, C.; Abdoulaye, T.; Dontsop-Nguezet, P.; Bamba, Z.; Manyong, V.; Shu, G. Determinant of University Students' Choices and Preferences of Agricultural Sub-Sector Engagement in Cameroon. Sustainability 2021, 13, 6564. [CrossRef] 